\title{
Arts and Drama Education Is for All
}

\author{
Kristen Witczak
}

\begin{abstract}
In this interview, arts educator Kristen Witczak discusses her experience of teaching drama with children, adolescents, and adults in various educational settings. She shares her early motivation for becoming an arts educator and the moments in her career that nourished her passion for her work. She also outlines some of the institutional and cultural challenges that are prevalent for today's drama educators. Finally, she shares advice for young artists who are considering a career in arts education.
\end{abstract}

Can you talk about how you got into teaching and, more specifically, drama education, and what your current position is at Saint-Lambert International High School?

The story of how I got into teaching and how I became a drama educator are really one story and it's probably my favourite story to tell. When I was young, I loved going to the theatre and the first show I ever saw, my mom took me to a college production of Charlotte's Web. I was so enchanted with that and always was interested in pursuing the theatre as a hobby. In CEGEP I did a double degree in Liberal Arts and Theatre and eventually went on to do a theatre degree at Concordia.

By the time I was at Concordia I wasn't really thinking about teaching at all anymore. I didn't have any particular interest at that point in pursuing arts education, but someone I knew had contacted me saying someone they knew was looking for an assistant on a theatre project with children. The woman who was running the project was a teacher at the National Theatre School. At that point I thought, "Oh well, I'Il go on to the National Theatre School, maybe, after my degree at Concordia; it can't hurt to go and be her assistant on this project." I showed up at an elementary school in Westmount on a Thursday afternoon; I was in my early twenties and still at Concordia at that point, and they were doing a youth production of Midsummer Night's Dream. I didn't really know what to expect, there were lots of small kids, they were really little, 9, 10, 11 years old. I went to the rehearsal and was assigned a group of kids to work with and was trying to help them out. So, I have all these little kids around me and they're asking for help and at the end of the rehearsal, time was up and I looked down and there were all these little kids around me at my feet and they all kept saying, "Miss Kristen, next week can you help me? Next week can it be my turn?" I looked down at the kids, looked back up, and I knew I was never going to go to the National Theatre School. I knew I was going to be an arts educator from just that tiny little moment. Starting with that experience, I ended up specializing my degree in teaching at Concordia. I taught a few semesters' worth of a class called Theatre Performance for Non-Theatre Students. I was teaching adults at Concordia, which was a huge, amazing learning experience. At that point, I had worked with young kids and had worked with adults. I felt like my personal interest might fall somewhere in the middle, which is how I ended up going back to school and becoming a high school teacher. 
I started my career at a very large English high school on the South Shore and, when I was there, I was teaching drama primarily and was also the Head of Drama for a specialized program. I did that for four years. When my number came up for a permanent post, I was transferred to a much smaller school in the board, an IB school, and I've been there for about eight years. I've since become the IB coordinator and moved into a hybrid teaching and administrative role. So that is what I do now. I am the IB coordinator, I do some administrative support—sort of like a teaching vice-principal—and I also teach. I'm not teaching drama anymore, because the school is very small and if a group doesn't open, there won't be a class. When there is a group, I do teach it.

Can you talk about the philosophy you have that informs your teaching of drama education?

When I try to prioritize what I care about as a drama educator, the thing that really comes to mind is encouraging creativity and a freedom of expression with students. Having been a student of drama in the youth sector and eventually through my postsecondary education, there was a lot of focus on excellence, being the best, and auditioning well. As I have matured in my thinking about teaching, I really moved away from that kind of mindset and now think that drama education and arts education are for everybody. The kids who get the most out of those experiences are the least inclined to embrace it in a professional sense. If I had to get it down to one sentence, I'd say, "Arts education and drama education are for all." It's not about skill at the end of the day-it's about creativity and experience. Something really central to arts education and, particularly drama education, is working in community. And those are the things that at the end of the day I hope are coming through teaching and my curriculum that I design for my classrooms.

How does drama teaching inform your teaching of Secondary $V$ English and vice versa?

Coming from a background of being a drama teacher, I feel very at ease embracing a more creative attitude towards assessment in my classroom. I really love to focus my own course design on performance-based assessment in a broad sense, not necessarily in a theatrical sense. My experience as a drama educator makes me very comfortable getting "outside of the box."

My favourite project that I do with students and, unfortunately, this year, we just missed it, with the schools being closed, but my favourite project that I do over the course of the year with my Secondary $\mathrm{V}$ drama is a kind of literature circle with modern drama. We set up the project so that every circle in the class is a little production company. They have to read the play and then design and plan a production, that they then pitch to me and the rest of the class for money-like a Dragon's Den of theatre. The students have really enjoyed that project the past couple of years. The things that come out of it are just amazing. My favourite component of that project is the design element; it's not even the "stand up and act it out" part, it's the component where the students take the text and then they design costumes or sets or even I've had music students compose music to go with the text. I find that project so outside the box, and so much fun. And the kids get to experience literature in a very different way than they would sort of in that like staid, book sense. A play is meant to be heard; a play is meant to get up off the page. I think this project lets them explore the text in its literary value, which of course is important for 
their overall skills in English, but it also lets them get up and be creative, get out of their chairs and act it out a little bit. It's a lot of fun and I like the texts we do too. Over the years, just refining what we chose, trying to get the right kid matched to the right text. It's a lot of fun and a really alive process in the classroom.

As the coordinator of the middle years IB Program, do you find that you use some of what you have learned in performance art in this leadership position?

For me a sort of innate sense of fun and theatricality makes getting up in front of the staff a lot less intimidating. I really don't have an issue positioning myself in a little bit of a humorous light, which breaks a lot of tension and it's also hard when power-wise, it's lateral but responsibility-wise it's not. You really have to think creatively about how you are going to bring your colleagues to the work, how you're going to engage your peers and colleagues in a way that doesn't feel too hierarchical. I think that my creative style translates well when I'm working with my colleagues. I think that by taking a more colourful approach, it's disarming. That is the best way to put it.

Can you give an example of one time when you used your creative and more performance propensity to change something in a meeting or something among staff?

The first thing that came to mind when you said that, was something I developed in concert with one of our student services technicians once the evaluation was done, the visit was over: we wanted to vision individually as teachers, within departments and then harmonized all together to vision together. I needed to find the logical person to speak to about something like that. I knew I could lead it, but I didn't really know how to design it, so I sought out my colleague Patty. We developed a Wheel of Life template about all the different aspects of the program and ran with that with the staff. We were asking people about their values and what they cared about using the Wheel of Life as a measurement tool. It was a very qualitative way to be looking at a long-term plan for a school.

I remember feeling quite proud that we had taken a very creative tack on what could have been an extremely dry process. The other thing about that was that it didn't feel top-down, that it didn't feel like at the end of the day I knew what I wanted, and our principal knew what he wanted and those couple of very involved teachers knew what they wanted. It didn't feel as though we were just taking information in from the staff to check a box saying, "Oh, you were consulted, you were consulted." We actually did something with it. Looking at processes like that, creatively, can really help move things forward in an authentic way.

In the next question I was going to ask you about examples of your successes in drama education in terms of process or product. You kind of broached that from the leadership perspective. Can you add a little more to that?

The last time that I taught Secondary IV Drama was in the same year as the Stoneman Douglas shootings in Florida. My plan for that year had been to do a collective creation with students in a regular drama classroom, which was something I'd never tried before. A collective creation involves students coming together to develop their own piece of theatre as a large group, from the ground up. So, if you have a group of 30, you're doing a fairly large piece with that group of 30 where the students are choosing their own topic, researching, writing, developing their own piece. 
When we first sat down to work on it, we brainstormed different ideas of topics we could pursue. The students decided that they wanted to pursue the topic of gun violence in schools. It was an incredible experience because as a teacher in that setting, you're only teaching the process. You don't have a very heavy hand in the product. Often kids want you to fine-tune the product, they want it to look good. The process-it's very difficult to get kids to value process, but in that kind of project it's all process. What the kids came up with at the end was just incredible. It moved me beyond what I expected could happen. I remember at the end they unfurled this giant banner and they had created a slogan that was written across this banner. The students had all portrayed multiple roles in the piece, so they had been police officers and protesters and students and teachers, and seeing them all up there at the end in their various costumes, some dressed up like a police officer, some the students, some the teacher, holding this banner together and they were making such a strong statement about putting an end to school violence. It felt important. And it felt like the students were actually engaging in something deeply meaningful to them. We had an audience of other students in the school to see it and it was a very powerful shared experience, to see something that was honest and also not polished, in the sense that you didn't want it to look perfect, you just wanted the kids to live it for real. When I think back on really powerful experiences, the collective creation is definitely one.

Can you describe some of the challenges you face in this performance art?

There are a few challenges facing drama educators specifically right now. Some are cultural and some are institutional. I think that there's often a sense of the priorities in a school being so firmly in one place: they need to pass their Grade 10 History, they need to pass their Grade 10 Science, Math, and with reason. As a language teacher I absolutely understand where we as core teachers are coming from when we make those kinds of statements, but I think that the more I continue looking at education as an interdisciplinary or transdisciplinary space, the more I know that the arts have incredible value. Often, we make sense of the world, we make sense of science, we make sense of history through art. It's a vessel with which we understand what we're learning and can share what we're learning. On the institutional side, I think that one of the challenges is just creating that innate sense of value for the arts in schools.

On the cultural side, and I think that's almost more difficult, when you talk to people about drama education or you talk to kids about drama education, often they have a very narrow view of what that's all about and that translates to what kids want to do in the classroom. An example of that is that you get a lot of this American Idol culture around performing arts where you come into the classroom and the goal of a drama class for the students in their minds is to be at the front, making people laugh, getting a lot of attention. Breaking down that culture can be really challenging because from a classroom management perspective students with that attitude often take up a lot of space and when you try to work on those issues there is not a lot of broader parental or outside-the-school understanding of that's not what arts education is about. It's a really slow process to create a culture of a specific art in the school, be it music, visual art, drama, when there isn't a long preexisting culture already in place. It's an uphill fight for the first couple of years, I found, in any school, to have my perspective of arts education or my attitude towards arts education grow into something that's valued. It's not easy. It is really not easy because every year you have to start again with those 30 kids in your class who are saying, "Oh well, you know, I thought I was just going to be doing improv like Whose Line Is It Anyway? all day...for a year." And when you say, "Well we're going to be doing a mask unit, we're going to be doing a mime unit, and you're not going to be speaking for an audience at all," it's really hard to combat what the 
students think it is versus what it is versus what it could be. You want to move with your students into that sort of space of infinite possibility and there's a lot of steps and hurdles you need to go through to get to that end.

What advice would you give to teachers wishing to venture into the era of drama education?

"Do it!" would be my first thought. I think that a lot of young artists who are in arts in postsecondary education think of teaching as a fallback. They think, "If you can't do, teach. Oh, I'Il go out and audition for a few years and if that doesn't work out, I'Il become a drama teacher." But if you have that fire in you and that passion for sharing what you know and giving kids opportunities to be creative, then that's why you should become a drama educator. Not because you went out there for a few years and it didn't work out but because you - to kind of reflect back on my own experience-look down on a group of kids saying, "Next week, can you help me? I want to do it too." Those are the moments that inform the right reasons to go out and do it. Teaching in the arts is an incredible gift that you give yourself as an artist, that you give to students as budding artists and it's the best job in the world to be in a creative space with children, whether you are teaching English and you are bringing your creativity to that, or you're teaching science and you're bringing your creativity to that. But if you have the skill and the patience and the love of sharing creativity with children, being an arts educator is the most wonderful thing that you can be doing with your life. It's a total, total joy.

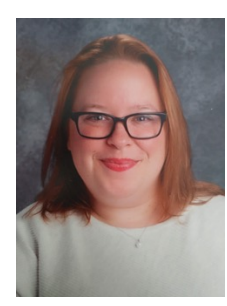

Kristen Witczak, BFA, BEd, is an English teacher and arts educator with a background in the performing arts. She has a BFA in Theatre from Concordia University and completed her teacher training at OISE/University of Toronto. She is a teacher and administrator at Saint-Lambert International High School in suburban Montreal. She is also a proud member of the Narrative Inquiry Group. Kristen's research interests include performance ethnography, narrative inquiry, arts-based research, and self-study. She is looking forward to pursuing graduate studies in the near future. 
Kristen Witczak

40 | LEARNing Landscapes | Spring 2020, Vol. 13 